\title{
Patient delays and system delays in breast cancer treatment in developed and developing countries
}

\author{
$\mathrm{O}$ atraso de paciente e atraso de sistema no tratamento do câncer \\ de mama nos países desenvolvidos e em desenvolvimento
}

Programa de PósGraduação em Saúde Pública, Universidade Estadual da Paraíba. R. Baraúnas 351, Universitário. 58429-500 Campina Grande PB Brasil. angela-rn@hotmail.com

\begin{abstract}
Delays in treating breast cancer have been associated with a more advanced stage of the disease and a decrease in patient survival rates. The scope of this integrative review was to analyze the main causal factors and types of patient and system delays. The underlying causal factors of delays were compared among studies conducted in developing and developed countries. Of the 53 studies selected, 24 were carried out in developing countries and 29 in developed countries, respectively. Non-attribution of symptoms to cancer, fear of the disease and treatment and low educational level were the most frequent causes of patient delay. Less comprehensive health insurance coverage, older/younger age and false negative diagnosis tests were the three most common causal factors of system delay. The effects of factors such as age were not decisive per se and depended mainly on the social and cultural context. Some factors caused both patient delay and system delay. Studies conducted in developing countries identified more causal factors of patient delay and had a stronger focus on patient delay or the combination of both. Studies conducted in developed countries had a stronger focus on aspects of system delay during treatment and guidance of breast cancer patients in the health care system.
\end{abstract}

Key words Breast cancer, Delay, Treatment, Developing countries, Developed countries
Resumo $O$ atraso no tratamento de câncer de mama foi associado com o aumento do palco da doença e a diminuição da sobrevida do paciente. O objetivo desta revisão integrativa foi a analise dos principais fatores causais e dos tipos de atraso. Sendo estes comparados entre estudos de países em desenvolvimento e desenvolvidos. Dos 53 estudos selecionados, 24 eram de países em desenvolvimento e 29 de países desenvolvidos, respectivamente. A não atribuição dos sintomas ao câncer, o medo e a menor escolaridade foram as causas mais citadas do atraso de paciente ao tratamento. Seguro menos abrangente, idade e testes diagnósticos falsos negativos foram às causas mais comuns identificadas do atraso do sistema. O efeito de vários fatores como o fator idade, dependeu principalmente do contexto social e cultural. Alguns fatores causaram tanto atraso relacionado ao paciente quanto ao sistema. Os estudos dos países em desenvolvimento identificaram mais fatores causais do atraso relacionado ao paciente, focando mais forte neste referido fator ou na combinação com o de sistema. Enquanto estudos de países desenvolvidos enfocaram com maior frequência aspectos do atraso de sistema durante o tratamento e a orientação de pacientes no sistema de saúde.

Palavras chave Câncer de mama, Atraso, Tratamento, Países em desenvolvimento, Países desenvolvidos 


\section{Introduction}

Breast cancer is the most common type of cancer among women worldwide, with about 1.67 million new cases diagnosed in the year 2012 $2^{1,2}$. The incidence of breast cancer is still high in developed countries, but the global burden of the disease is progressively shifting to developing countries $^{1,2}$. More than $70 \%$ of breast cancer patients in developed countries are diagnosed at stages I and II, whereas in low and middle-income countries, only $20-60 \%$ of patients are diagnosed in early stages of the disease ${ }^{3}$. Breast cancer stage represents an important prognostic factor and advanced stage is associated with decreased time of disease-free survival and increased mortality rates $^{4,5}$. The mortality-to-incidence ratio of developing countries tended to be lower, compared to that of developed countries, largely due to the fact that patients have the disease at more advanced stages ${ }^{6,7}$. Furthermore, previous studies have shown that care delay associated with increased stage had a negative effect on the survival of breast cancer patients and were more common among patients in developing countries ${ }^{3,4,8,9}$.

In literature, care delay has been subdivided in patient delay (PD) and health care system (SD) delay ${ }^{3,10}$. According to Lee Caplan (2014), PD is a delay in seeking medical attention after self-discovering a potential breast cancer symptom, whereas SD is a delay within the health care system $^{10}$. PD was mainly defined as a time gap $>3$ month between symptom detection and first medical consultation ${ }^{3}$. The socio-economic and cultural background of patients can contribute to $\mathrm{PD}^{3,10}$. Furthermore, symptomatology experience, ethnic origin, beliefs or perceptions that affect attitudes of patients represent important causal factors of $\mathrm{PD}^{3,10-12}$. SD can refer to access barriers, like long distance to treating health care centers, or no availability of specialized centers and intrinsic problems of an established health care system, like disease management, problems in obtaining or scheduling diagnostic tests and communication problems between patients and physicians $s^{3,10,11,13}$. Furthermore, to reduce SD, health services must fit with the socio-economic and cultural or ethnic background of patients ${ }^{3,11}$.

Despite the existence of vast literature about breast cancer care delays only few authors have compared studies conducted at different regions of the world. Review articles are mainly focused on care delays and its outcomes in developing countries $^{3,8}$. Little is known about differences of study objectives and the causal factors of PD and SD, identified by authors of distinct regions of the world. The present integrative review addressed on four main questions: 1 . What are the main causal factors of PD and SD in literature? 2. What are the methods applied to analyse the contribution of causal factors on PD and SD? 3. Which types of SD are analysed in literature? 4. If care delays and their adjacent causes are different among developing and developed countries.

\section{Method}

An integrative review of care delay associated with breast cancer was conducted. The research methodology was performed according to established criteria ${ }^{14}$. The operational steps were conducted as followed: Definition of exclusion and inclusion criteria and database; selection of studies; extraction of information and categorization; Analysis and interpretation of data; Interpretation of results; Synthesis and resume of results. The search was conducted in the following databases: Literatura Latino-Americana e do Caribe em Ciências da Saúde (LILACS); National Library of Medicine (MEDLINE), PubMed and in the repository Scientific Electronic Library Online (SciELO).

Terms "treatment delay", "provider delay", "system delay" and "patient delay" are commonly used in public health literature, but were not identified in Medical Subject Headings (MeSH; http://www.nlm.nih.gov/mesh/MBrowser.html) of the U. S. National Library of Medicine. Terms "breast cancer" and "delayed diagnosis" were selected from $\mathrm{MeSH}$. A much more common term in literature was "diagnostic delay". As shown in the results and discussion section, the term "diagnostic delay" was not very well defined. To identify a broader range of articles about any kind of care delay, the term "delayed diagnosis" was substituted by "delay". Therefore, the term "breast cancer" was used in combination with "delay" in English, Spanish ("Cáncer de mama" and "atraso") and Portuguese ("Câncer de mama" and "atraso").

The search was conducted on October 22, 2014. To establish an internal quality control, all procedure of literature selection was performed twice independently by each of the two authors. Application of search terms in MEDLINE led to the identification of 2390 articles. When filter " 10 years" was applied, this number reduced to 731 articles. Additional application of filter "free full text" led to the identification of 299 articles. In 
the SciELO database, 18 articles were identified and in the LILACS database, no article that met criteria of both search terms in any of the three languages was identified.

Finally, 317 articles were used for further analysis. To identify articles that met selective criteria, title and abstract were analysed. The following inclusion criteria were applied: original research article or research communication, available for free and published over the last five years, in English, Spanish or Portuguese. Articles identified in more than one database, articles about breast cancer that did not deal with care delays and review articles were excluded from the study. For further method categorization, result and discussion sections were read and analysed. According to previous studies, PD was defined as a delay of medical consultation caused by the patients behaviour ${ }^{3,10}$. The term SD was applied in the case of any delay caused by the health care system. In the case of factors associated to PD and SD, only factors that were identified two or more times were included and factors identified only by one study were excluded. This was justified by the fact that in the case of factors like "smoking" that was identified only one time by a single study, authors did not explain any possible causal relationship with PD and/or SD.

In accordance with the International Monetary Fund (2014), the following were defined as developing economies ${ }^{15}$ : Brazil, Cameron, Colombia, Egypt, India, Iran, Lybia, Malaysia, Nigeria, Pakistan, Poland, Thailand, Tunisia and Turkey (Table 1).

All statistical analysis was performed on Prism $^{\text {TM }}$ software vers.6 (GraphPad, La Jolla, California, USA). The $\chi^{2-}$ Test was performed to analyse categorized variables.

\section{Results and discussion}

All together 53 studies were identified that originated from 22 different countries (Table 1). Of the 53 studies, 24 were from developing and 29 from developed countries, respectively (Table 1). Single studies originated from Australia, Denmark, Estonia, China (Hong Kong), Iran, Libya, Nigeria, Pakistan, Poland, South Korea, Thailand, Turkey and Egypt (Table 1). More than one study was carried out in Brazil $(\mathrm{N}=2)$, Cameroon ( $\mathrm{N}$ $=2)$, Tunisia $(\mathrm{N}=2)$, India $(\mathrm{N}=2)$, Colombia $(\mathrm{N}=3)$, United Kingdom $(\mathrm{N}=3)$, Malaysia $(\mathrm{N}=$ $6)$ and the USA $(\mathrm{N}=21)$. With exception of one Brazilian study written in Portuguese, a Colom- bian study written in Spanish and a study carried out in Tunisia written in French, all the other 50 studies were written in English (Table 1) ${ }^{16-18}$.

Many contributions in the form of articles, such as those carried out in Malaysia and USA could indicate a greater interest of researchers in delay issues in these countries. Alternatively, the distribution of contributions by countries may not reflect the real frequency of publications within the last five years: Contributions were not included in the present research if they were not published in open access journals or if they were published in journals that are not registered in the examined databases. Therefore, exclusion criteria could have led to a bias in the number of contributions from single countries. This is a serious limitation of the present study and results should be interpreted with care.

\section{Methodological background of studies}

The most prominent methodological approach $(\mathrm{N}=28)$ to obtain data about $\mathrm{PD}$ and SD was interview (Table 1). Of these 28 studies, 20 were exclusively based on interviews, whereas eight studies used additionally medical records or other registered data (Table 1). Several qualitative studies $(\mathrm{N}=7)$ including small sample numbers, $<20$ persons applied in-depth-interview (Table 1). Furthermore, of these 28 studies, four were based on telephone interviews (Table $1)^{19-22}$. Questionnaires were applied in five studies and in one case, it was combined with registered data (Table 1) ) $^{23-27}$. Of the 53 studies, 18 collected data exclusively of medical records or other source of recorded data (Table 1). Several of these authors obtained increased numbers of data from breast cancer patients, that varied from 21.818 to 147.682 by the usage of large data bases as source for sampling (Table 1$)^{28-31}$. One study was based on lecture of media and the other on discussed theories, concepts and models of care delay without sampling data (Table 1$)^{32,33}$.

Several studies $(\mathrm{N}=18)$ applied descriptive methods without any significance test (Table 1). Most studies were based on $<30$ samples $(\mathrm{N}=$ $11)$ and 30 to $50(\mathrm{~N}=4)$, and only three were based on studies $\geq 100$ samples (Table 1$)^{16,27,34}$. All in-depth-interviews belonged to this group of studies.

Other studies $(\mathrm{N}=12)$ applied univariate methods, mainly using $\chi^{2-}$ Test or Fisher's exact test to analyse categorized variables and the t-Test to analyse continuous variables. Máslach et al. ${ }^{35}$, for example, compared time delays between 


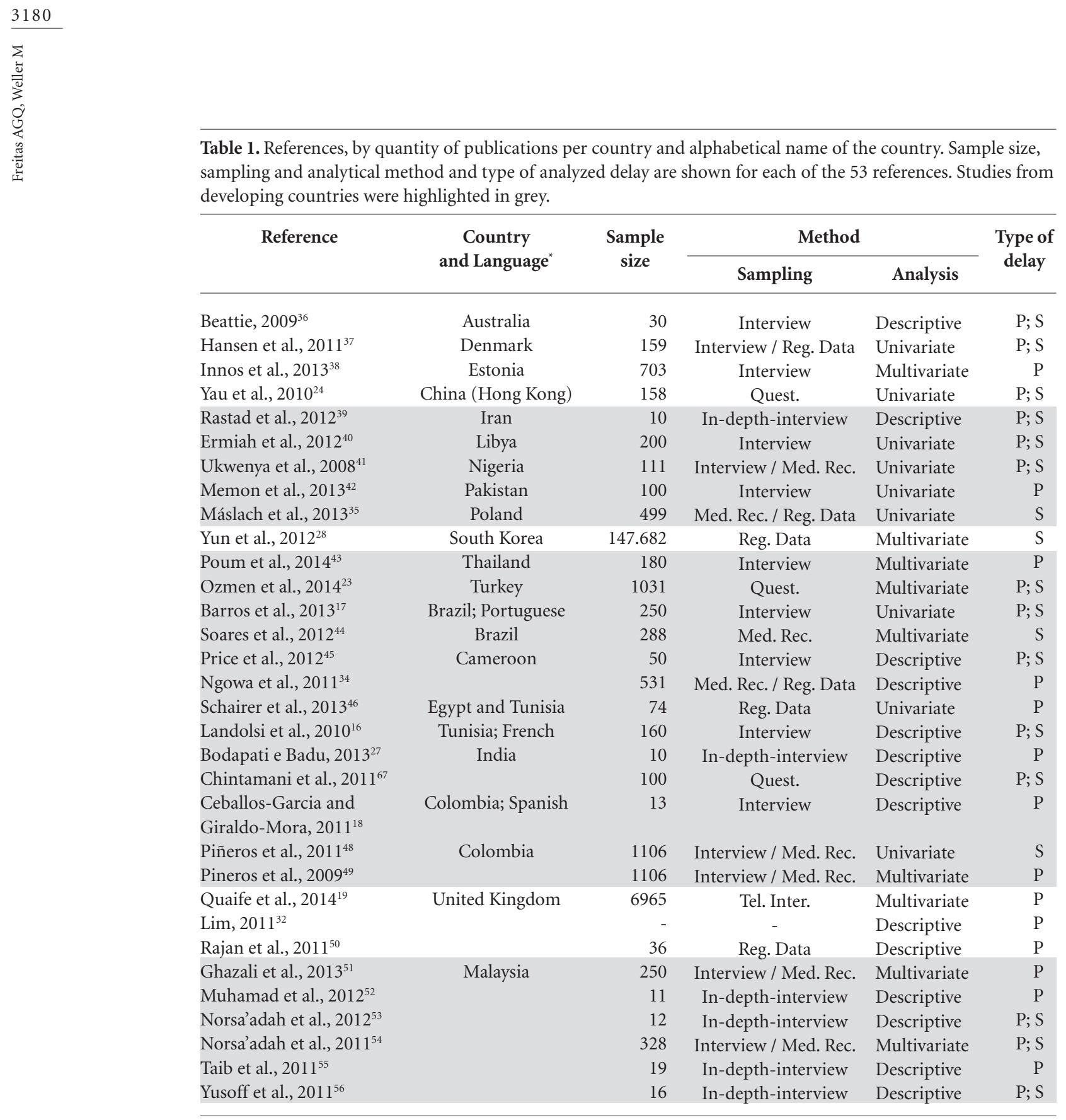

it continues

patients from rural and urban regions. Crowley et al. ${ }^{57}$ compared the time gap from diagnosis to start of adjuvant hormone therapy among patients of Afro-American, Hispanic and Caucasian ethnicity. In these studies, each factor potentially contributing to care delay was analysed as a univariate variable, regardless of all the other study variables. To identify independent factors and to establish a model that could explain PD or SD, most authors $(\mathrm{N}=23)$ adopted multivariate regression models (Table 1). Multivariate logistic regression models were applied on dichotomized data comparing two groups: Ghazali et $a .^{51}$ for example, determined PD as a time gap of $>3$ month from symptom discovery to first medical consultation. The authors first categorized patients into two groups, those with delay $>3$ month and those with no delay $(\leq 3 \text { month })^{51}$. After identification of significant factors by univariate analysis $\left(\chi^{2-}\right.$ Test), a multivariate logistic regression model was established to explain PD based on martial status (divorced or single $v s$. married), ethnicity (Chinese vs. Malay or Indian) and breast self examination (not performed $v s$. 


\begin{tabular}{|c|c|c|c|c|c|}
\hline \multirow[t]{2}{*}{ Reference } & \multirow{2}{*}{$\begin{array}{c}\text { Country } \\
\text { and Language }\end{array}$} & \multirow{2}{*}{$\begin{array}{l}\text { Sample } \\
\text { size }\end{array}$} & \multicolumn{2}{|l|}{ Method } & \multirow{2}{*}{$\begin{array}{l}\text { Type of } \\
\text { delay }\end{array}$} \\
\hline & & & Sampling & Analysis & \\
\hline Bustami et al., $2014^{58}$ & United States of America & 3071 & Reg. Data & Multivariate & S \\
\hline Crowley et al., $2014^{57}$ & & 113 & Med. Rec. / Reg. Data & Univariate & $\mathrm{P} ; \mathrm{S}$ \\
\hline Thind et al., $2014^{20}$ & & 924 & Tel. Inter. & Multivariate & S \\
\hline Fedewa et al., $2010^{29}$ & & 107.587 & Reg. Data & Multivariate & S \\
\hline Bourdeanu et al., $2013^{59}$ & & 40 & Quest. & Descriptive & $\mathrm{P} ; \mathrm{S}$ \\
\hline McGee et al., 2013 & & 601 & Interview / Med. Rec. & Multivariate & S \\
\hline Fayanju et al., $2013^{26}$ & & 52 & Interview & Multivariate & $\mathrm{P}$ \\
\hline Ramirez et al., $2013^{61}$ & & 260 & Med. Rec. & Multivariate & S \\
\hline Sharma et al., $2013^{62}$ & & 90 & Reg. Data & Multivariate & $\mathrm{P}$ \\
\hline Sheppard et al., $2013^{22}$ & & 359 & Tel. Inter. / Med. Rec. & Multivariate & $\mathrm{P}, \mathrm{S}$ \\
\hline Black and Woods- & & Social & Lecture of media & Descriptive & $\mathrm{P}$ \\
\hline Giscombé, $2012^{33}$ & & media & & & \\
\hline Bleicher et al., 2012 $2^{30}$ & & 72.586 & Reg. Data & Multivariate & S \\
\hline Vandergrift et al., $2012^{63}$ & & 6622 & Reg. Data & Multivariate & S \\
\hline Karliner et al., $2012^{25}$ & & 4027 & Reg. Data / Quest. & Univariate & S \\
\hline Partridge et al., $2012^{31}$ & & 21.818 & Reg. Data & Multivariate & $\mathrm{P}$ \\
\hline Simon et al., $2012^{64}$ & & 2234 & Reg. Data & Multivariate & S \\
\hline Heisey et al., 2011 $1^{65}$ & & 14 & In-depth-interview & Descriptive & $\mathrm{P}$ \\
\hline Maly et al., $2011^{21}$ & & 921 & Tel. Inter. & Multivariate & $\mathrm{P}, \mathrm{S}$ \\
\hline Simmons et al., $2011^{66}$ & & 12 & Reg. Data & Descriptive & $P ; S$ \\
\hline Wujcik et al., $2009^{67}$ & & 4336 & Reg. Data & Multivariate & S \\
\hline Lobb et al., $2010^{68}$ & & 2252 & Reg. Data & Univariate & S \\
\hline
\end{tabular}

Abbreviations: E= English; Reg. Data= Registered data of a database; Tel. Inter.= Telephone interview; Med. Rec.= Medical records; $\mathrm{P}=$ Patient delay; Quest. $=$ Questionnaire; $\mathrm{S}=$ System delay. ${ }^{\star}$ English, if not differently indicated.

performed $)^{51}$. These approaches were exemplary for most studies aimed at identifying the main factors that affect PD and/or SD and multivariate regression models were standard to identify independent causal variables of PD and SD.

The association between advanced stage of breast cancer and care delays is well established in literature ${ }^{3,10}$. In several studies, PD was associated with or identified as a causal factor of advanced stage of breast cancer ${ }^{26,31,40,49-51,53}$. In a study carried out in Tunisia, PD and also long distances to health care centres contributed to advanced stage of the disease ${ }^{16}$. Soares et al. $^{44}$, showed that SD, caused by increased length of time between clinical suspicion and diagnostic confirmation, was associated with advanced stage of breast cancer.

Most studies have focused on breast cancer patients for sampling, but there were also some exceptions: In a study carried out in Malaysia, the authors investigated the preference of patients for western or traditional medicine and interviewed 11 breast cancer survivors ${ }^{52}$. Telephone interviews were applied to 6965 women in England, who were not breast cancer patients ${ }^{19}$. The authors used a validated questionnaire named "Awareness and Beliefs about Cancer Measure (ABC)" to analyse causal factors of $\mathrm{PD}^{19}$. Black and Woods-Giscombé ${ }^{33}$, used the narratives of non-patients to apply a gender-specific, culturally responsive stress process framework to identify the reasons why Afro Americans, compared to women of other ethnic groups, have more often PD.

These publications show that sources for sampling data were heterogeneous. Exceptionally in this context was also the study by Schairer et al. ${ }^{46}$, who investigated if patients with inflammatory breast cancer, compared to those with other types of breast cancer, have a different help seeking behaviour. The authors used registered data and did not find any significant difference ${ }^{46}$.

\section{Different types of SD \\ and the terminology of diagnosis delay}

The different types of SD were analysed by the authors and summarized in Chart 1. In the 


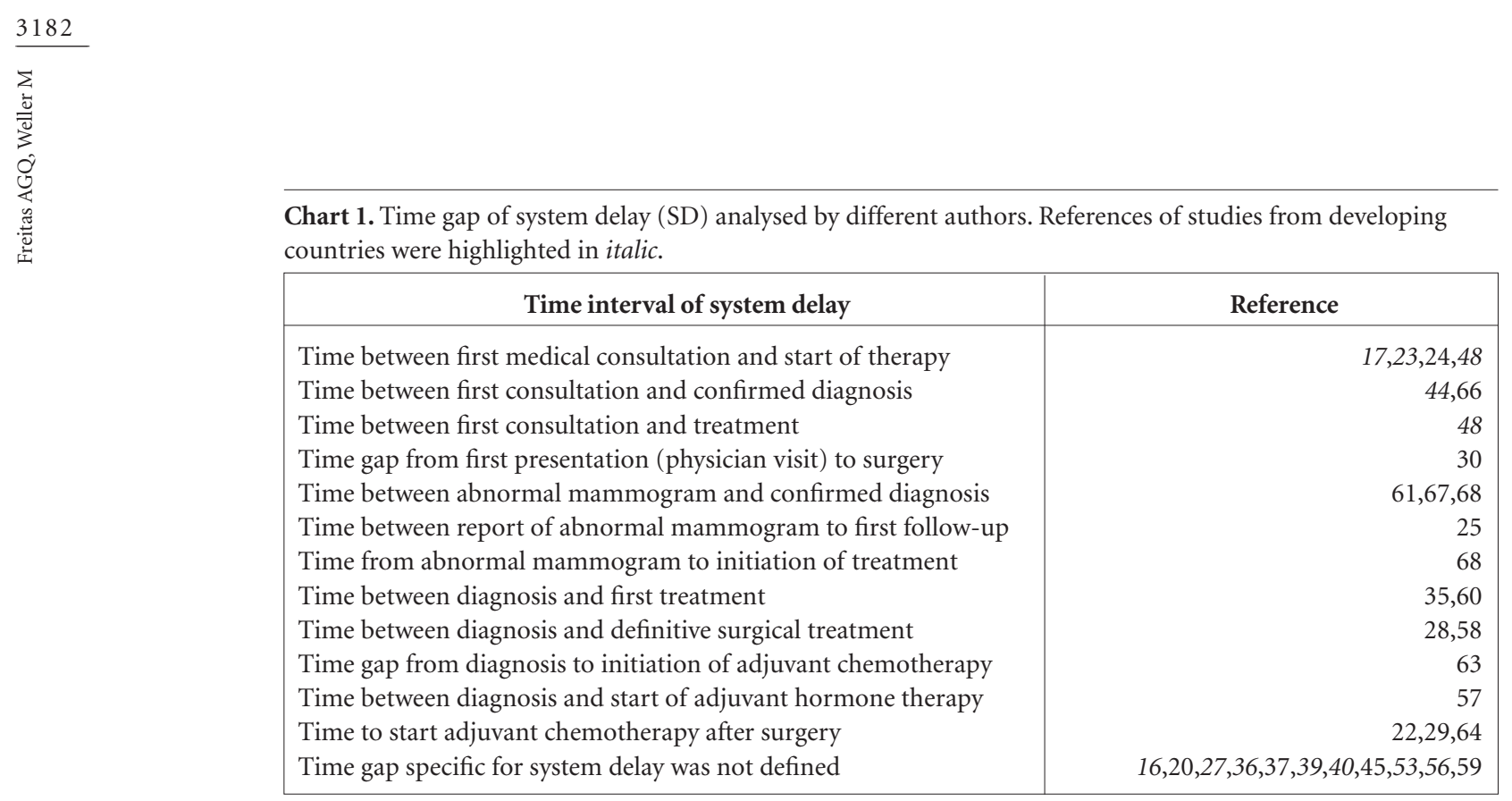

Abbreviations: E= English; Reg. Data= Registered data of a database; Tel. Inter.= Telephone interview; Med. Rec.= Medical records; $\mathrm{P}=$ Patient delay; Quest.= Questionnaire; $\mathrm{S}=$ System delay. ${ }^{*}$ English, if not differently indicated.

case of 11 studies, a specific time gap of SD has not been defined (Chart 1). With the exception of one study ${ }^{20}$, in 10 of these 11 studies focused on PD and SD, underlying causal factors were generally attributed either to $\mathrm{PD}$ or SD. A time gap of SD was defined in 16 studies carried out in developed countries and six studies carried out in developing countries (Chart 1). In contrast, four studies of developed and seven of developing countries, have not defined a time gap of SD (Chart $1 ; \mathrm{p}=0.0439$ ). This indicates that studies carried out in developing countries had a more generalized approach to SD compared to studies carried out in developed countries, which more often defined a specific time gap of SD.

The most common form of SD analysed was the time gap between first medical consultation and start of any type of therapy (Chart 1$)^{17,23,24,48}$. Other studies focused on more specific SD attributed it to different phases of breast cancer treatment, for example between diagnosis and chemotherapy, hormone therapy or surgical treatment (Chart 1$)^{28,57,58,63}$. Yun et al..$^{28}$ defined in their study "surgical treatment delay" as the time gap between diagnosis and first surgical treatment.

Different definitions were applied for the term "diagnostic delay": Several authors defined diagnostic delay as the time gap from recognition of first symptoms to histological diagnosis ${ }^{21,40,54}$. In this case, there was no clear distinction between PD and SD by the time gap analysed, but underlying causal factors such as access barriers or patient attitudes have been attributed either to PD or SD. Other studies have defined diagnostic delay as the time gap between first presentation and final diagnosis ${ }^{36,66}$, or suspected breast cancer and confirmed diagnosis ${ }^{44}$. Finally, "diagnostic delay" was also defined as the time gap from abnormal mammogram to diagnostic resolu$\operatorname{tion}^{67,68}$. Other terms also applied were "provider delay" 11,48 , "doctor delay" 53,56 and "treatment delay" 28 . In general, there is no standardized nomenclature, as identical terms have distinct meanings and may refer to different time gaps.

\section{Study objectives differ quantitatively and qualitatively between developing and developed countries}

Of the 53 studies, 19 and 15 focused exclusively on PD or SD, respectively, whereas other 19 studies analysed both PD and SD (Table 1). All together, studies exclusively focused on SD were more frequently carried out in developed countries $(\mathrm{N}=12)$ compared to developing countries $(\mathrm{N}=3)$, whereas in the case of studies more focused on PD or both, PD and SD, the difference between developed $(\mathrm{N}=17)$ and developing countries $(\mathrm{N}=21)$ was smaller $(\mathrm{p}=0.0313)$. Five out of six studies, that attributed poor knowledge or no information about breast cancer to affected women, were from developing countries ${ }^{34,42,47,55,56}$ (Chart 2). The basic assumption that women are not well informed about breast cancer may lead authors from these countries to develop a strong- 
Chart 2. Factors identified to cause patient delay (PD) and their corresponding references. References of studies from developing countries were highlighted in italic.

\begin{tabular}{|c|c|}
\hline Factor & Reference \\
\hline \multicolumn{2}{|l|}{ Socioeconomic factors } \\
\hline Lower educational level and literacy status & $16,17,19,23,33,40-42,49,62$ \\
\hline Financial costs too high or no health insurance & $16,27,47,49,57,59,62$ \\
\hline Older age & $19,27,38,40,49,62$ \\
\hline Younger age & $23,31,41$ \\
\hline Martial status: Single or divorced & $19,22,26,42,51$ \\
\hline No family history of breast cancer & $16,42,66$ \\
\hline Lower family income & 24,49 \\
\hline Higher family income & 22 \\
\hline \multicolumn{2}{|l|}{ Symptomatology experience } \\
\hline Non-attribution of symptoms to cancer & $\begin{array}{r}16,19,23,34,36,39,42,47,49,51 \\
53,59,62,66\end{array}$ \\
\hline Ignorance or negligence of symptoms & $19,39,45,47,53,59$ \\
\hline Other symptoms than breast lump or breast pain & $23,38,40,56,65$ \\
\hline Previous benign or harmless breast complaint & $38,40,65$ \\
\hline Painless breast lump vs. other symptoms & 42,56 \\
\hline \multicolumn{2}{|l|}{ Attitudes of patients } \\
\hline Fear of disease, treatment adverse effects, examination and chemotherapy & $18,38,39,42,47,53,56,57,59,62$ \\
\hline Family and career commitments and no support from family and friends & $18,23,39,42,53,59,65$ \\
\hline Reliance on traditional healers or preference for alternative treatment & $27,34,41,42,45,54,56$ \\
\hline No breast self examination & $16,19,40,51$ \\
\hline No participation on mammography screening program & $21,31,32,36,38,48$ \\
\hline $\begin{array}{l}\text { No acceptance of hospital treatment or distrust in success of therapy and } \\
\text { medical system }\end{array}$ & $22,23,41,54$ \\
\hline Poor knowledge of the disease and its outcomes & $42,47,55$ \\
\hline $\begin{array}{l}\text { No information about breast cancer from affected women, family } \\
\text { members or other sources }\end{array}$ & $34,38,56$ \\
\hline A comorbid condition & $29,57,65$ \\
\hline Previous negative health care experience & 18,65 \\
\hline Fear of social isolation and sanctions by relatives & 42,53 \\
\hline Strong religious beliefs or religious fatalism & 22,56 \\
\hline \multicolumn{2}{|l|}{ Ethnic differences } \\
\hline $\begin{array}{l}\text { Afro Americans, Latin American and Asian versus Caucasian ethnicity or } \\
\text { Chinese versus Malay and Indian ethnicity }\end{array}$ & $19,49,51,57$ \\
\hline
\end{tabular}

er focus on PD or PD and SD compared to authors from developed countries.

Identified causal factors of PD and SD were summarized in Table 3 and Table 4, respectively. Overall, in 53 studies, 208 factors were identified two or more times (Chart 2 and Chart 3). Of these 208 identified causal factors, 124 contributed to PD and 84 to SD (Chart 2 and Chart 3 ). The number of identified factors that contributed to PD was higher for studies carried out in developing countries $(\mathrm{N}=74)$ compared to developed countries $(\mathrm{N}=50)$ and in the case of $\mathrm{SD}$, the opposite was observed: More factors were identified in studies carried out in developed countries $(\mathrm{N}$ $=57)$, compared to developing countries $(\mathrm{N}=$ $27 ; \mathrm{p}=0.0001)$. This underlines the strong in- terest of authors from developing countries to better understand the reasons of PD.

\section{Causal factors and PD terminology}

Non-attribution of symptoms to cancer ( $\mathrm{N}$ $=14$ ), fear of disease, treatment adverse effects, examination and chemotherapy $(\mathrm{N}=10)$, low educational level and literacy level $(\mathrm{N}=10)$, and old or young age $(\mathrm{N}=9)$ were the four most often identified causal factors of PD (Chart 2). The following factors were exclusively identified by studies carried out in developing countries: Reliance on traditional healers or preference for alternative treatment $(\mathrm{N}=7)$, no breast self examination $(\mathrm{N}$ $=4$ ), poor knowledge of the disease and its out- 


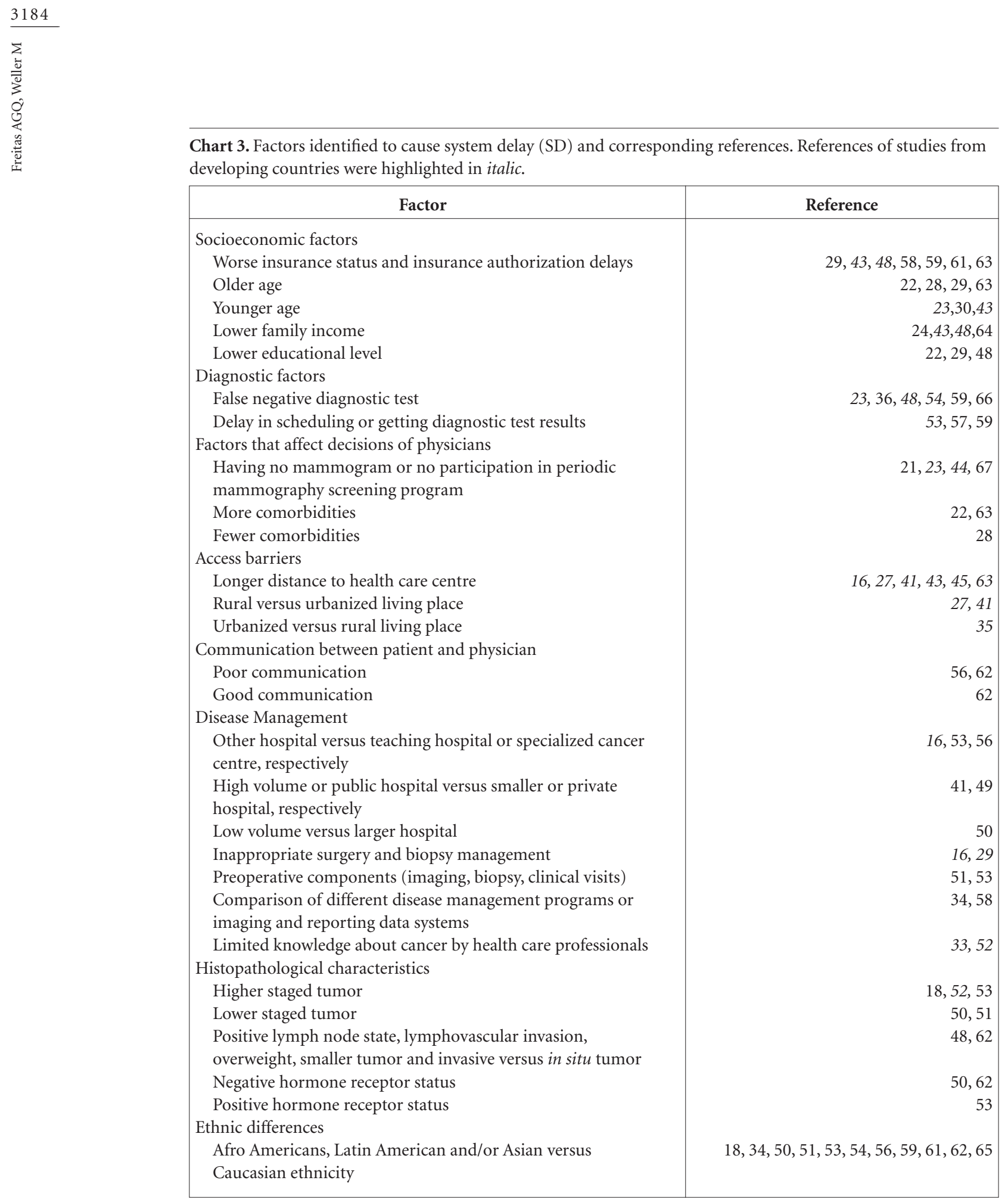

comes $(\mathrm{N}=3)$, fear of social isolation $(\mathrm{N}=2)$ and painless breast lump vs. other symptoms $(\mathrm{N}=2$; Chart 2). Comorbid condition $(\mathrm{N}=3)$ was the only factor identified exclusively in studies carried out in developed countries (Chart 2) 29,57,65.

The term PD was generally used for care delays that were dependent on patient behaviour. The au- thors who categorized data from patients defined $\mathrm{PD}$ as the time gap $>3$ month from recognition of first symptoms to first medical visit ${ }^{42,43,48,49,51,62}$. Alternatively, no time gap was identified and patients were not categorized. In this case, PD was determined as a continuous variable or described by more detailed in-depth-interviews based on 


\section{Causal factors of SD}

Poor insurance status and insurance authorization delays $(\mathrm{N}=7)$, older or younger age $(\mathrm{N}$ $=7)$, false negative diagnostic tests $(\mathrm{N}=6)$ and longer distance to health care centre $(\mathrm{N}=6)$ were the four most common identified causal factors of SD (Chart 3). In the case of older patients increased time gap between diagnosis and adjuvant chemotherapeutic treatment was explained by postoperative complications and diagnostic or therapeutic interventions ${ }^{29,63}$. Vandergrift et al. additionally showed that missing supplemental insurance of Afro-American women also increased this time gap ${ }^{63}$. Authors of studies carried out in Colombia and Thailand argued that poor insurance status was associated with delayed diagnosis and referral for specialist treatment $t^{43,48}$.

The factors comorbidity, communication, hospital volume, preoperative components, comparison of disease management program, several histopathological characteristics and ethnicity were exclusively identified to cause SD by authors of developed countries (Chart 3). Studies of developed countries had generally a stronger focus on the performance of the health care system and patient navigation during the treatment process.

\section{Effects of several factors depend on the context, but are not decisive themselves and some factors can cause PD and SD}

Long distances to health care centres and rural vs. urban areas were identified in several studies to cause SD as they are relevant access barriers (Chart 3$)^{16,23,27,41,45,63}$. In a study carried out in Poland, the opposite was observed, as women living in urban areas suffered from $\mathrm{SD}^{35}$. In this case, the authors argued that physicians concentrate treatment procedures for patients from rural regions to reduce the number of visits. Similarly, comorbidities or clinical-histopathological characteristics like tumour stage and hormone receptor status influenced decisions of physicians in different context-dependent ways (Chart 2).

Lobb et al. ${ }^{68}$, pointed out that improved communication between patient and physician can

reduce health system barriers. Sheppard et al. ${ }^{22}$ identified in their study an ambivalent nature of better communication that was dependent on the ethnic origin of patients (Chart 3):Better communication between patients and physicians led to decreased SD among Afro-American patients and to increased SD among patients of Caucasian origin ${ }^{22}$. According to their interpretation, Afro-American women may have relied on provider suggestion, whereas women of Caucasian origin with higher income and education rather seek information outside the patient-provider relationship to make their decisions ${ }^{22}$.

Several studies have identified older age as an causal factor of PD (Chart 2) 19,27,38,40,49,62. In their study, Inos et al. ${ }^{38}$, pointed out that older women tend to underestimate the risk of breast cancer as breast cancer screening programs are mainly addressed to women aged 50-62 years. This is in agreement with findings of Brazilian studies that revealed decreased numbers of elderly women participating in mammography screening programs ${ }^{69,70}$. Similarly, in a study carried out in Lybia, PD was attributed to older aged women with poor knowledge about breast cancer ${ }^{40}$. In contrast, a study carried out in Turkey, the authors showed that young women aged 30-39 years more often ignored breast cancer symptoms compared with older patients ${ }^{23}$. Ozmen et al. ${ }^{23}$, also identified in their study decreased SD among patients aged $>60$ years. Their interpretation was that older patients are prioritized by physicians and receive a faster diagnostic process. Similarly, Bleicher et al. $^{30}$, identified increased preoperative delay in patients aged 65-79 years compared to patients $>80$ years. Interestingly, authors of a study based on 21,818 breast cancer cases, argued that symptomatic presentation of disease was more common in younger women ${ }^{31}$. In this case young age $\leq 40$ years, was a significant variable of $\mathrm{PD}$ in univariate analysis, but did not represent an independent variable of the final regression model.

In several cases, the authors did not explain why a determined factor had a unexpected effect: While in two studies, low family income was associated with PD, in a study carried out in Thailand, the opposite was verified and authors did not represent a causal argument of their result (Chart 2) 24,43,49.

As shown above in the case of age, some factors caused PD and SD. Lower educational level and lower family income were also associated with PD and SD (Chart 2 and 3). Lower educational level and literacy status were the most often 
cited factor to cause PD (Chart 2). A Colombian study revealed that SD was not only associated with poor health insurance status, but also with low family income and educational level ${ }^{48}$. Fedewa et al. ${ }^{29}$, used a large database to compare the time gap between surgical resection of the primary tumour and initiation of chemotherapy among patients from different regions of the USA. Their study revealed that $\mathrm{SD}>90$ days was not only more prominent among Afro-Americans, compared to patients of Caucasian origin, but that proportionally more often patients from regions with low education levels, measured by the frequency of school diploma, also suffered from $\mathrm{SD}^{29}$. The authors reported that lower socio-economic and educational status can also difficult navigation through the health care system ${ }^{66,68}$.

These studies showed that several factors are not decisive, but depend on patient's social and cultural environment and on differences among health care systems and their personal decisions. Furthermore, several socio-economic factors have an influence on both PD and SD.

\section{Final considerations}

Studies carried out in developing countries more often focus on the general aspects of SD. In contrast, studies carried out in developed countries analysed more often a determined time gap of treatment. In general, authors from developing countries are more interested in PD or PD and SD combinations, and identified also more causal factors of PD compared to studies carried out in developed countries. In contrast, studies carried out in developed countries more often focus on specific aspects of SD. The stronger focus on PD in the case of studies carried out in developing countries is probably influenced by the author's assumption that patients in their country are not well informed about breast cancer. However, this does not necessarily mean that women from developed countries are really well informed. One should always keep in mind that questions of studies and their objectives are not only influenced by the social and cultural reality of researchers, but that there also can exist underlying "fashions of research" that differ timely and locally among countries.

The present review study showed that methodological approaches of studies were highly different. Interviews of few persons contrasted with the analysis of large databases, and while some studies were purely descriptive, others applied multivariate regression models to identify a reduced number of independent variables. Neither methodological approaches nor nomenclature about PD and SD are standardized.

Socio-economic factors, symptomatology experience and attitudes of patients contributed to PD. Socioeconomic and ethnic differences affected both PD and SD. Additionally, diagnostic factors, factors that affect decisions of physicians, access barriers, communication between patient and physician, disease management and histopathological characteristics of disease also affected SD. Some of these factors were not decisive, but mainly dependent on the social and cultural context. 


\section{Collaborations}

AGQ Freitas contributed to the selection process of literature. M Weller contributed to the selection process of literature and was responsible for study design and manuscript draft.

\section{References}

1. Benson JR, Jatoi I. The global breast cancer burden. Future Oncol 2012; 8(6):697-702.

2. Ferlay J, Soerjomataram I, Dikshit R, Eser S, Mathers C, Rebelo M, Parkin DM, Forman D, Bray F. Cancer incidence and mortality worldwide: Sources, methods and major patterns in GLOBOCAN 2012. Int J Cancer 2014; 136(5):E359-386

3. Unger-Saldaña K. Challenges to the early diagnosis and treatment of breast cancer in developing countries. World J Clin Oncol 2014; 5(3):465-477.

4. Arndt V, Stürmer T, Stegmaier C, Ziegler H, Dhom G, Brenner H. Patient delay and stage of diagnosis among breast cancer patients in Germany - a population based study. Br J Cancer 2002; 86(7):1034-1040.

5. Howlader N, Noone A, Krapcho M, Neyman N, Aminou R, Altekruse S, Kosary C, Ruhl J, Tatalovich Z, Cho H, Mariotto A, Eisner M, Lewis D, Chen H, Feuer E, Cronin Ke. SEER Cancer Statistics Review, 1975-2009 (vintage 2009 populations). Bethesda: National Cancer Institute; 2012.

6. Asadzadeh Vostakolaei F, Karim-Kos HE, Janssen- Heijnen ML, Visser O, Verbeek AL, Kiemeney LA. The validity of the mortality to incidence ratio as a proxy for sitespecific cancer survival. Eur J Public Health 2011; 21(5):573-577.

7. Porter PL. Global trends in breast cancer incidence and mortality. Salud Publica Mex 2009; 51(Supl. 2):s141146.

8. Sharma K, Costas A, Shulman LN, Meara JG. A systematic review of barriers to breast cancer care in developing countries resulting in delayed patient presentation. I Oncol 2012; 2012:121873.

9. Richards MA, Smith P, Ramirez AJ, Fentiman IS, Rubens RD. The influence on survival of delay in the presentation and treatment of symptomatic breast cancer. Br J Cancer 1999; 79(5-6):858-864.

10. Caplan L. Delay in Breast Cancer: Implications for stage at diagnosis and survival. Front Public Health $2014 ; 2: 87$.

11. Martins T, Hamilton W, Ukoumunne OC. Ethnic inequalities in time to diagnosis of cancer: a systematic review. BMC Fam Pract 2013; (23):14:197.

12. Mor V, Masterson-Alle S, Goldberg R, Guadagnoli E, Wool MS. Pre-diagnostic symptom recognition and help seeking among cancer patients J Community Health 1990; 15(4):253-266

13. Schwartsmann G. Breast cancer in South America: challenges to improve early detection and medical management of a public health problem. J Clin Oncol 2001; 19(18 Supl.):118S-124S.

14. Dal Sasso Mendes K, Campos Pereira Silveira RC, Galvão CM. Revisão integrativa: Método de pesquisa para a incorporação de evidências na saúde e na enfermagem. Texto Contexto Enferm 2008; 17(4):758-764.

15. World Economic Outlook 2014 (International Monetary Found). [cited 2014 Dic 01]. Available from: http://www.imf.org/external/pubs/ft/weo/2014/02/

16. Landolsi A, Gahbiche S, Chaafii R, Chabchoub I, Ben Fatma L, Hochlef M, Gharbi O, Ahmed SB. Reasons of diagnosis delay of breast cancer in Tunisian women (160 patients in central region of Tunisia). Tunis Med 2010; 88(12):894-897. 
17. Barros FA, Uemura G, Soares de Macedo JL. Tempo para acesso ao tratamento do câncer de mama no Distrito Federal, Brasil Central. Rev Bras Ginecol Obstet 2013; 35(10):458-463.

18. Ceballos-García GY, Giraldo-Mora CV. "Autobarreras" de las mujeres al diagnóstico y tratamiento oportuno del cáncer de mama. Aquichán 2011; 11(2):140-157.

19. Quaife SL, Forbes LJL, Ramirez AJ, Brain KE, Donnelly C, Simon AE, Wardle J. Recognition of cancer warning signs and anticipated delay in help-seeking in a population sample of adults in the UK. Br J Cancer 2014; 110(1):12-18.

20. Thind A, Hoq L, Diamant A and Maly RC. Satisfaction with Care among Low-Income Women with Breast Cancer. J Womens Health (Larchmt) 2010; 19(1):77-86.

21. Maly RC, Leak B, Mojica CM, Liu Y, Diamant AL, Thind A. What Influences Diagnostic Delay in Low-Income Women with Breast Cancer J Womens Healt (Larchmt) 2011; 20(7):1017-1023

22. Sheppard VB, Isaacs C, Luta G, Willey SC, Boisvert M, Harper FWK, Smith K, Horton S, Liu MC, Jennings Y, Hirpa F, Snead F, Mandelblatt JS. Narrowing Racial Gaps in Breast Cancer Chemotherapy Initiation: The Role of the Patient-Provider Relationship. Breast Cancer Res Treat 2013; 139(1):207-216.

23. Ozmen V, Boylu S, Ok E, Canturk NZ, Celik V, Kapkac M, Girgin S, Tireli M, Ihtiyar E, Demircan O, Baskan MS, Koyuncu A, Tasdelen I, Dumanli E, Ozdener F, Zaborek P. Factors affecting breast cancer treatment delay in Turkey: a study from Turkish Federation of Breast Diseases Societies. Eur J Public Health 2014; 25(1):9-14.

24. Yau TK, Choi CW, Ng E, Yeung R, Soong IS, Lee AWM. Delayed presentation of symptomatic breast cancers in Hong Kong: experience in a public cancer center. Hong Kong Med J 2010; 16(5):373-377.

25. Karliner LS, Hofmann M, Kerlikowske K. Language Barriers, Location of Care and Delays in Follow-up of Abnormal Mammograms. Med Care 2012; 50(2):171178

26. Fayanju OM, Jeffe DB, Elmore L, Ksiazek DN, Margenthaler JA. Patient and Process Factors Associated with Late-Stage Breast Cancer Diagnosis in Safety-Net Patients: A Pilot Prospective Study. Ann Surg Oncol 2013; 20(3):723-732.

27. Chintamani, Tuteja A, Khandelwal R, Tandon M, Bamal R, Jain S, Narayan N, Srinivas S, Kumar Y. Patient and provider delays in breast cancer patients attending a tertiary care centre: a prospective study. $J R$ Soc Med Sh Rep 2011; 2:76.

28. Yun YH, Kim YA, Min YH, Park S, Won YJ, Kim DY, Choi IJ, Kim YW, Park SJ, Kim JH, Lee DH, Yoon SJ, Jeong SY, Noh DY, Heo DS. The influence of hospital volume and surgical treatment delay on long-term survival after cancer surgery. Annals of Oncology 2012; 23(10):2731-2737

29. Fedewa SA, Ward EM, Stewart AK, Edge SB. Delays in Adjuvant Chemotherapy Treatment Among Patients With Breast Cancer Are More Likely in African American and Hispanic Populations: A National Cohort Study 2004-2006. J Clin Oncol 2010; 28(27):4135-4141.

30. Bleicher RJ, Ruth K, Sigurdson ER, Ross E, Wong YN Patel SA, Boraas M, Topham NS, Egleston BL. Preoperative Delays in the US Medicare Population With Breast Cancer. J Clin Oncol 2012; 30(36):4485-4492.
31. Partridge $\mathrm{AH}$, Hughes ME, Ottesen RA, Wong $\mathrm{YN}$ Edge SB, Theriault RL, Blaney DW, Niland JC, Winer EP, Weeks JC, Tamimi RM. The Effect of Age on Delay in Diagnosis and Stage of Breast Cancer. Oncologist 2012; 17(6):775-782.

32. Lim JNW. Empirical Comparisons of Patient Delay and Help Seeking Models for Breast Cancer: Fitness of Models for Use and Generalisation. Asian Pacific J Cancer Prev 2011; 12(6):1589-1595.

33. Black AR, Woods-Giscombé C. Applying the Stress and 'Strength' Hypothesis to Black Women's Breast Cancer Screening Delays. Stress Health 2012; 28(5):389-396.

34. Ngowa JDK, Yomi J, Kasia JM, Mawamba Y, Ekortarh AC, Vlastos G. Breast Cancer Profile in a Group of Patients Followed up at the Radiation Therapy Unit of the Yaounde General Hospital, Cameroon. Obstet Gynecol Int 2011; 2011:143506

35. Maślach D, Krzyżak M, Szpak A, Owoc A, Magdalena Bielska-Lasota. Waiting time for treatment of women with breast cancer in Podlaskie Voivodeship (Poland) in view of place of residence. A population study. Anna Agric Environ Med 2013; 20(1)161-166.

36. Beattie A. Detecting breast cancer in a general practice - Like finding needles in a haystack? Aust Fam Physician 2009; 38(12):1003-1006.

37. Hansen RP, Vedsted P, Sokolowski I, Søndergaard J, Olesen F. Time intervals from first symptom to treatment of cancer: a cohort study of 2,212 newly diagnosed cancer patients BMC Health Serv Res 2011; 11:284.

38. Innos K, Padrik P, Valvere V, Eelma E, Kütner R, Le htsaar J, Tekkel M. Identifying women at risk for delayed presentation of breast cancer: a cross-sectional study in Estonia. BMC Public Health 2013; 13:947.

39. Rastad H, Khanjani N, Khandani BK. Causes of Delay in Seeking Treatment in Patients with Breast Cancer in Iran: a Qualitative Content Analysis Study. Asian Pac J Cancer Prev 2012; 13(9):4511-4515.

40. Ermiah E, Abdalla F, Buhmeida A, Larbesh E, Pyrhönen S, Collan Y. Diagnosis delay in Libyan female breast cancer BMC Res Notes 2012; 21(5):452.

41. Ukwenya AY, Yusufu LMD, Nmadu PT, Garbaa ES Ahmed A. Delayed treatment of symptomatic breast cancer: The experience from Kaduna, Nigeria. $S$ Afr Surg 2008; 46(4):106-110.

42. Memon ZA, Shaikh AN, Rizwan S, Sardar MB. Reasons for Patient's Delay in Diagnosis of Breast Carcinoma in Pakistan. Asian Pac J Cancer Prev 2013; 14(12):74097414.

43. Poum A, Promthet S, Duffy SW, Maxwell Parkin D. Factors Associated With Delayed Diagnosis of Breast Cancer in Northeast Thailand. J Epidemiol 2014; 24(2):102-108

44. Soares PBM, Quirino Filho S, Pereira de Souza W, Gonçalves RCR, Reis B. Martelli DRB, Fagundes Silveira M, Martelli Júnior H. Characteristics of women with breast cancer seen at reference services in the North of Minas Gerais. Rev Bras Epidemiol 2012; 15(3):595-604

45. Price AJ, Ndom P, Atenguena E, Nouemssi JPM, Ryder RW. Cancer Care Challenges in Developing Countries. Cancer 2012; 118(14):3627-3635 
46. Schairer C, Soliman AS, Omar S, Khaled H, Eissa S, Ayed FB, Khalafallah S, Ayoub WB, Kantor ED, Merajver S, Swain SM, Gail M, Morris Brown L. Assessment of diagnosis of inflammatory breast cancer cases at two cancer centers in Egypt and Tunisia. Cancer Med 2013; 2(2):178-184.

47. Bodapati SL, Babu GR. Oncologist Perspectives on Breast Cancer Screening in India - Results from a Qualitative Study in Andhra Pradesh. Asian Pac J Cancer Prev 2013; 14(10):5817-5823.

48. Piñeros M, Sánchez RM, Perry F, García OA, Ocampo $\mathrm{R}$, Cendales R. Demoras en el diagnóstico y tratamiento de mujeres con cáncer de mama en Bogotá, Colombia. Salud Publica Mex 2011; 53(6):478-485.

49. Piñeros M, Sánchez R, Cendales R, Perry F, Ocampo R. Patient delay among Colombian women with breast cancer. Salud Publica Mex 2009; 51(5):372-380.

50. Rajan SS, Lim JNW, Haq A. Late Presentation and Management of South Asian Breast Cancer Patients in West Yorkshire, United Kingdom Asian Pac J Cancer Prev 2011; 12(6):1615-1628.

51. Ghazali SM, Othman Z, Cheong KC, Hock LK, Rozita W, Mahiyuddin W, Kamaluddin MA, Yusoff AF, Mustafa AN. Non-Practice of Breast Self Examination and Marital Status are Associated with Delayed Presentation with Breast Cancer Asian Pacific J Cancer Prev 2013; 14(2):1141-1145.

52. Muhamad M, Merriam S, Suhami N. Why Breast Cancer Patients Seek Traditional Healers. Int J Breast Cancer 2012; 2012:689168.

53. Norsa'adah B, Rahmah MA, Rampal KG, Knight A. Understanding Barriers to Malaysian Women with Breast Cancer Seeking Help. Asian Pac J Cancer Prev 2012; 13(8):3723-3730.

54. Norsa'adah B, Rampal KG, Rahmah MA, Nyi N, Naing NN, Biswal BM. Diagnosis delay of breast cancer and its associated factors in Malaysian women. BMC Cancer 2011; 11:141.

55. Taib NA, Yip CH, Low WY. Recognizing Symptoms of Breast Cancer as a Reason for Delayed Presentation in Asian Women - The Psycho-sociocultural Model for Breast Symptom Appraisal: Opportunities for Intervention. Asian Pacific J Cancer Prev 2011; 12(6):16011608

56. Yusoff N, Taib NAM, Ahmad A. The Health Seeking Trajectories of Malaysian Women and their Husbands in Delay Cases of Breast Cancer: A Qualitative Study Asian Pac J Cancer Prev 2011; 12(10):2563-2570.

57. Crowley MM, McCoy ME, Bak SM, Caron SE, Ko NY, Kachnic LA, Alvis F, Battaglia TA. Challenges in the Delivery of Quality Breast Cancer Care: Initiation of Adjuvant Hormone Therapy at an Urban Safety Net Hospital. J Oncol Pract 2014; 10(2):e107-112.

58. Bustami RT, Shulkin DB, Nancy O'Donnell N, Whitman ED. Variations in time to receiving first surgical treatment for breast cancer as a function of racial/ ethnic background: a cohort study. JRSM Open 2014; 5(7):2042533313515863.

59. Bourdeanu L, Luu T, Baker N, Swain-Cabriales S, Chung CT, Mortimer J, Hurria A, Helton S, Smith D, Ferrell B, Juarez G, Somlo G. Barriers to Treatment in Patients With Locally Advanced Breast Cancer. J Nat Compr Canc Netw 2013; 11(10):1193-1198.
60. McGee SA, Durham DD, Tse CK, Millikan RC. Determinants of breast cancer treatment delay differ for African American and White women Cancer. Epidemiol Biomarkers Prev 2013; 22(7):1227-1238.

61. Ramirez AG, Pérez-Stable EJ, Talavera GA, Penedo FJ, Carrillo JE, Fernandez EF, Muñoz E, Long Parma D, Holden AEC, San Miguel de Majors S, Nápoles A, Castañeda SF, Gallion KJ. Time to definitive diagnosis of breast cancer in Latina and non-Hispanic white women: the six cities study. Springerplus 2013; 2(1):84.

62. Sharma K, Costas A, Damuse R, Hamiltong-Pierre J, Pyda J, Ong CT, Shulman LN and Meara JG. The Haiti Breast Cancer Initiative: Initial Findings and Analysis of Barriers-to-Care Delaying Patient Presentation. J Oncol 2013; 2013:206367.

63. Vandergrift JL, Niland JC, Theriault RL, Edge SB, Wong YN, Loftus LS, Breslin TM, Hudis CA, Javid SH, Rugo HS, SilverSM, Lepisto EM, Weeks JC. Time to Adjuvant Chemotherapy for Breast Cancer in National Comprehensive Cancer Network Institutions. J Natl Cancer Inst. 2013; 105(24):1912.

64. Simon MS, Lamerato L, Krajenta R, Booza JC, Ruterbusch JJ, Kunz S, Schwartz K. Racial Differences in the Use of Adjuvant Chemotherapy for Breast Cancer in a Large Urban Integrated Health System. Int J Breast Cancer 2012; 2012:453985.

65. Heisey R, Clemons M, Granek L, Fergus K, Hum S, B. McCready DR, Fitzgerald B. Health care strategies to promote earlier presentation of symptomatic breast cancer: perspectives of women and family physicians Curr Oncol 2011; 18(5):227-237.

66. Simmons PS, Jayasinghe YL, Wold LE, Melton LJ. Breast Carcinoma in Young Women. Obstet Gynecol 2011; 118(3):529-536

67. Wujcik D, Shyr Y, Li M, Clayton MF, Ellington L, Menon U, Mooney K. Delay in Diagnostic Testing After Abnormal Mammography in Low-Income Women. Oncol Nurs Forum 2009; 36(6):709-715.

68. Lobb R, Allen JD, Emmons KM, Ayanian JZ. Timely Care After an Abnormal Mammogram Among Low-Income Women in a Public Breast Cancer Screening Program. Arch Intern Med 2010; 170(6):521-528.

69. Dias dos Santos G, Sato Chubaci RY. O conhecimento sobre o câncer de mama e a mamografia das mulheres idosas frequentadoras de centros de convivência em São Paulo (SP, Brasil). Cien Saude Colet 2011; 16(5):2533-2540

70. Xavier Gouveia de Oliveira E, Sobrino Pinheiro R, Praates Melo EC, Sá Carvalho M. Condicionantes socioeconômicos e geográficos do acesso à mamografia no Brasil, 2003-2008. Cien Saude Colet 2011; 16(9):36493664.

Artigo apresentado em 29/11/2014

Aprovado em 29/01/2015

Versão final apresentada em 31/01/2015 